\title{
Altered Placental and Fetal Expression of IGFs and IGF-Binding Proteins Associated With Intrauterine Growth Restriction in Fetal Sheep During Early and Mid-Pregnancy
}

\author{
BARBRA DE VRIJER, MEREDITH L. DAVIDSEN, RANDALL B. WILKENING, RUSSELL V. ANTHONY, AND \\ TIMOTHY R.H. REGNAULT
}

Department of Obstetrics and Gynecology [B.V.], Division of Obstetrics and Prenatal Medicine, Erasmus University Medical Center, 3000 CB Rotterdam, The Netherlands; Department of Pediatrics [B.V., M.L.D., R.B.W., R.V.A., T.R.H.R.], Division of Perinatal Medicine, Perinatal Research Center, University of Colorado Health Science Center, Aurora, CO 80045; Department of Biomedical Sciences [R.V.A.], Animal Reproduction and Biotechnology Laboratory, CO State University, Fort Collins, CO 80523

\begin{abstract}
The insulin-like growth factors (IGFs) are postulated to be altered in association with the development of intrauterine growth restriction (IUGR). The present studies examined placental and fetal hepatic mRNA concentration of components of the IGF system at two time points (55 and $90 \mathrm{~d}$ gestational age, dGA; Term 147 dGA) in a hyperthermia (HT)-induced sheep model of placental insufficiency-IUGR. Maternal plasma insulin and IGF-I were constant at 55 and $90 \mathrm{dGA}$ and were unaffected by treatment. Umbilical vein insulin concentrations tended to be reduced at $90 \mathrm{dGA}$ following HT exposure. Caruncle IGF-I mRNA was increased at $90 \mathrm{dGA}$ in HT placentae $(p<0.05)$, while cotyledon concentrations were constant over gestation and unaltered by treatment. In control cotyledons, IGF-II mRNA concentration increased $(p<0.01)$ and IGFBP-3 decreased between 55 and $90 \mathrm{dGA}(p<0.01)$. Cotyledon IGF-II and caruncle IGFBP-4 mRNA were elevated at 55 dGA in HT placentae compared with control ( $p<0.01$ and $p<0.05$ respectively). Fetal hepatic IGF-I, IGFBP-2, -3 and -4 concentrations rose over gestation $(p<0.05)$, but there were no treatment effects. These data suggest that changes in placental IGF expression in early and mid gestation may predispose the pregnancy to placental insufficiency, resulting in inadequate substrate supply to the developing fetus later in gestation. (Pediatr Res 60: 507-512, 2006)
\end{abstract}

$\mathrm{T}$ The insulin-like growth factors, IGF-I and -II, are mitogenic polypeptides that play essential roles in conceptus cell proliferation, differentiation and metabolism. The IGFbinding proteins (IGFBP-1-IGFBP-6) regulate IGF bioavailability, modulating the biologic effects of the IGFs, in addition to acting as growth factors independent of the IGFs (1). The importance of these growth factors and their associated binding proteins in the etiology of fetal growth restriction (IUGR) has been highlighted through gene deletion models in mice (2).

Received March 6, 2006; accepted June 10, 2006.

Correspondence: Barbra de Vrijer, M.D., Department of Obstetrics and Gynaecology, University of Western Ontario, St. Joseph's Health Care, 268 Grosvenor Street, Room B3-041, London, Ontario N6A 4V2, CANADA; e-mail: bdevrije@uwo.ca

Supported by NIH-NICHD RO1 HD20761 and HD41505.

DOI: 10.1203/01.PDR.0000242364.78002.71
The fetal liver is the primary source of IGFs and IGFBPs in fetal circulation (3). IGF-I concentrations in fetal circulation have been found to be reduced in several animal models of IUGR, suggesting that alterations in IGF-I production and/or availability may contribute to disorders of fetal growth (4). In humans, fetal plasma IGF-I concentration is positively correlated with birth weight (5) and is reduced in IUGR (6). Significant increases in fetal hepatic IGFBP-1 and -2 have been observed in animal models of IUGR, late in pregnancy, and these increases are postulated to exert an inhibitory effect on the growth promoting action of IGF-I during fetal life (7). Additionally, several studies report increases in IGFBP-4, and decreases in IGFBP-3 in IUGR fetal circulation $(8,9)$.

A rapid phase of placental growth precedes fetal growth, and in the sheep, maximal placental growth occurs between 40 and $80 \mathrm{~d}$ gestational age (dGA), peaking at approximately 55 dGA (term $147 \mathrm{dGA}$ ), with the majority of fetal growth occurring after $100 \mathrm{dGA}(10)$. The IGF/IGFBP axis has been described for the sheep placenta (11) and fetus (12), although placental studies have concentrated on localization rather than quantification during early pregnancy (11). Additionally, studies concerning nutritional restriction-induced sheep IUGR have reported changes in the IGF axis in mid- to late gestation $(13,14)$. Pregnant sheep subjected to elevated environmental temperatures (hyperthermia, HT) for the period of early and mid-gestation (40-120 dGA), produce a fetus whose placental, body and liver weights are significantly reduced at term, $45 \%, 50 \%$, and $45 \%$, respectively $(15,16)$. This asymmetrically restricted IUGR fetus is the result of placental insufficiency and shares many characteristics with the severe human

Abbreviations: bp, basepair; CBT, core body temperature; dGA, days gestational age; HT, hyperthermia; IGFBP, insulin-like growth factor binding protein; RPA, ribonuclease protection assay; TN, thermoneutral control 
IUGR fetus, including hypoglycemia, hypoxia and an increased brain-liver ratio (17).

While IGFs and their binding proteins have been extensively studied in fetal and placental growth, studies investigating interactions of IGFs in disorders of fetal growth have concentrated on late gestation IUGR. Considering the chronic developmental nature of this condition, and the role the IGFs and the binding proteins play in placental and fetal development, it is important to understand the ontogenic changes that may occur in the IGFs and IGFBPs throughout the development of IUGR. The present studies examine the ontogeny of the IGFs, and their alterations during the development of placental insufficiency induced IUGR.

\section{MATERIALS AND METHODS}

Biologic preparation. Twenty-one time-mated 2- to 3-y-old ColumbiaRambouillet ewes pregnant with a single fetus were used. Animal care was in strict compliance with National Institutes of Health guidelines within an American Association for Accreditation of Laboratory Animal Care certified facility, and the University of Colorado Health Sciences Center Animal Care and Use Committee approved the study. Surgery was performed at 32-37 dGA to insert core body temperature (CBT) transmitters (18). Approximately 2-4 d after surgery, once core body temperature was $39.2^{\circ} \mathrm{C}$, ewes were allocated to either the control (thermoneutral; TN) or HT treatment. A total of 10 ewes were maintained in the TN regime, and a further 11 ewes were moved to individual pens in a HT chamber (Bainbridge, Marcellus, MI). The relevant temperature, lighting and feeding regimes used in this treatment are as previously described (18).

Experimental design and tissue preparation. Ewes were killed following one of the designated time points; at $55 \mathrm{dGA}$ (early gestation, $n=5$; TN and $n=6$; HT) or at $90 \mathrm{dGA}$ (mid gestation, $n=5$; TN and $n=5$; HT). Maternal arterial blood samples were collected approximately 2 d before autopsy, pre-feeding. At autopsy of the $90 \mathrm{dGA}$ animals, $2 \mathrm{~mL}$ of blood was drawn from the fetal umbilical vein, immediately after opening the uterus. The gravid uterus was removed and dissected into placental and fetal components, as previously described (19). With selected B type placentomes (20), we carefully separated the caruncle and cotyledon by squeezing the caruncle with gentle traction on the cotyledon (21). Fetal liver and brain was collected, weighed and the liver was snap frozen. Approximately 6-10 g of the frozen cotyledon, caruncle, and liver tissue was later ground under liquid nitrogen and stored at $-80^{\circ} \mathrm{C}$ until total cellular (tc) RNA extraction.

Plasma insulin and IGF-I concentrations. Insulin concentrations were determined using a Mercodia sheep insulin ELISA (Alpco, Windham, NH) (22). The interassay coefficients of variation were $2.1 \%$ and $9.7 \%$ for highand low-quality control samples, respectively, while the intra-assay coefficients of variation were $2.7 \%$ and $8.5 \%$, respectively. Plasma IGF-I was measured by immunoradiometric assay after extraction (Diagnostics Systems Laboratories, Inc, Webster, TX) as previously described (23). The interassay coefficients of variation were $8.3 \%$ and $7.2 \%$ for a high and low quality control sample respectively, while the intra-assay coefficients of variation were $1.5 \%$ and $1.3 \%$, respectively.

Construction and preparation of sheep cDNAs. Sheep IGF-I, -II and IGFBP-1, -2, -3 and -4 cDNAs were amplified by RT-PCR that corresponded to IGF-I; basepair (bp) 508 to 698 of Genbank Accession number M30653), IGF-II; (bp 342-839 of MN_001009311), IGFBP-1; (bp 556-735 of ×54979), IGFBP-2 (bp 645-413 of S44612), IGFBP-3 (bp 1029-693 of M76478), IGFBP-4 (bp 855-1083 of S77394). Reverse Transcriptase reactions were conducted using $1 \mu \mathrm{g}$ of $135 \mathrm{dGA}$ fetal hepatic tcRNA, $1 \mu \mathrm{L}(0.5 \mu \mathrm{g})$ of oligo $(\mathrm{dT})_{12-18}$ and Superscript II reverse transcriptase (Invitrogen Life Technologies, Carlsbad, CA). Thirty-five cycles of amplification were performed in the associated PCR, $1 \mathrm{~min}$ at $94^{\circ} \mathrm{C}, 1 \mathrm{~min}$ at $55^{\circ} \mathrm{C}$ (IGF-I), $58^{\circ} \mathrm{C}$ (IGF-II), $53^{\circ} \mathrm{C}$ (IGFBP-1), $60^{\circ} \mathrm{C}$ (IGFBP-2), $55^{\circ} \mathrm{C}$ (IGFBP-3) and $54^{\circ} \mathrm{C}$ (IGFBP-4), $1 \mathrm{~min}$ at $72^{\circ} \mathrm{C}$, and finally $10 \mathrm{~min}$ at $72^{\circ} \mathrm{C}$. Taq polymerase amplified PCR products were ligated into pCR II and transformed into Inv $\alpha \mathrm{F}^{\prime}$ E.coli cells (Invitrogen Corporation, Carlsbad, CA). Plasmids were purified as described and the insert was sequenced (Davis Sequencing, University of California, Davis, $\mathrm{CA}$ ) in both directions to verify authenticity. All cDNA sequence verification was performed using basic local alignment search tool (BLAST NCBI, M.D.). $\beta$-actin cDNA (bp 637-1135 of U39357) was generated as previously described (19).
RNA extraction, RNA probe synthesis and RNase protection assay. Fetal liver, caruncular and cotyledonary tcRNA was isolated using Tri-Reagent ${ }^{\circledR}$ (Molecular Research Center Inc) (19). The plasmid containing the cDNA fragment of interest was linearized with the appropriate restriction endonucleases (BamH1 or EcoRV). IGF-II, IGFBP-4 and $\beta$-actin were restricted with internal restriction endonucleases to yield shorter and more stable probes for RPA. The IGF-II cDNA was restricted with Fsp-1 (New England BioLabs, Beverly, MA), which when used in RPAs, displayed a protected fragment of 177 bp. IGFBP-4 was restricted with StyI (New England BioLabs) to yield a protected fragment of $179 \mathrm{bp}$, whilst $\beta$-actin was restricted with AvaII (New England BioLabs) to yield a protected fragment of $141 \mathrm{bp}$. Antisense $\left[\alpha-{ }^{32} \mathrm{P}\right] \mathrm{CTP}$ radiolabeled cRNAs $\left(2 \times 10^{5} \mathrm{cpm}\right)$ were synthesized by in vitro transcription using T3, Sp6 or T7 RNA polymerases (Ambion, Austin, TX) in the presence of unlabeled dNTPs. RNase protection assays were performed as previously described (19).

Statistical analysis. Maternal CBT analysis has been previously reported (18). Placental and fetal data were analyzed using Student's $t$-test. Tissue IGF-I, -II, IGFBP-1, -2, -3 , and -4 mRNA levels were normalized to $\beta$-actin mRNA, and analyzed using two-way ANOVA and Tukey's means-separation test.

\section{RESULTS}

Control TN ewes had a mean CBT throughout the study of $39.2 \pm 0.1^{\circ} \mathrm{C}$ and $55 \mathrm{dGA}$ HT ewes had elevated CBTs similar to those previously published for $90 \mathrm{dGA}$ HT ewes (Mean CBT $39.9^{\circ} \mathrm{C}$ ) (18). Placental weights were not significantly different at 55 dGA between treatments, though at 90 dGA, placental weights were approximately $70 \%$ of normal (Table 1). Fetal weights were similar at $55 \mathrm{dGA}$, but were significantly reduced at $90 \mathrm{dGA}$ (Table 1). Fetuses at both gestational ages displayed signs of hepatic growth restriction, resulting in a significant increase in brain/liver ratio at $55 \mathrm{dGA}$ (Table 1), and tending to be increased at $90 \mathrm{dGA}$. While fetal weight was unaltered at $55 \mathrm{dGA}$, placental weight was reduced to $74 \%$ of control, resulting in a significantly increased fetal/placental ratio at $55 \mathrm{dGA}$ (Table 1). There were however no significant differences in placental weight or fetal/placental ratio at $90 \mathrm{dGA}$.

Table 1. Placental and fetal weights, fetal CRL and associated ratios of TN and HT fetuses at 55 and $90 d G A$, following 15 and 55 days in treatment, respectively

\begin{tabular}{lccc}
\hline & TN & HT & $p$-value \\
\hline 55 dGA & $n=5$ & $n=6$ & \\
Gestational age $(\mathrm{d})$ & $55.60 \pm 0.40$ & $55.33 \pm 0.49$ & $\mathrm{~ns}$ \\
Placental weight $(\mathrm{g})$ & $177.31 \pm 17.28$ & $131.76 \pm 19.30$ & $\mathrm{~ns}$ \\
Fetal weight $(\mathrm{g})$ & $29.92 \pm 1.59$ & $30.15 \pm 2.55$ & $\mathrm{~ns}$ \\
Fetal/placental ratio & $0.17 \pm 0.01$ & $0.24 \pm 0.01$ & $<0.01$ \\
Brain weight $(\mathrm{g})$ & $1.30 \pm 0.07$ & $1.33 \pm 0.13$ & $\mathrm{~ns}$ \\
Liver weight $(\mathrm{g})$ & $2.27 \pm 0.17$ & $1.96 \pm 0.20$ & $\mathrm{~ns}$ \\
Brain/liver ratio & $0.58 \pm 0.03$ & $0.68 \pm 0.03$ & $<0.05$ \\
CRL (cm) & $9.66 \pm 0.51$ & $9.48 \pm 0.47$ & $\mathrm{~ns}$ \\
Ponderal index $\left(\mathrm{g} / \mathrm{cm}^{3}\right)$ & $3.54 \pm 0.59$ & $3.61 \pm 0.34$ & $\mathrm{~ns}$ \\
90 dGA & $n=5$ & $n=5$ & \\
Gestational age $(\mathrm{d})$ & $93.67 \pm 0.92$ & $92.50 \pm 1.03$ & $\mathrm{~ns}$ \\
Placental weight $(\mathrm{g})$ & $531.94 \pm 87.58$ & $354.90 \pm 52.63$ & $\mathrm{~ns}$ \\
Fetal weight $(\mathrm{g})$ & $676.23 \pm 45.58$ & $514.22 \pm 39.72$ & $<0.05$ \\
Fetal/placental ratio & $1.42 \pm 0.21$ & $1.63 \pm 0.26$ & $\mathrm{~ns}$ \\
Brain weight $(\mathrm{g})$ & $15.92 \pm 0.91$ & $13.18 \pm 1.10$ & $\mathrm{~ns}$ \\
Liver weight $(\mathrm{g})$ & $42.43 \pm 5.42$ & $27.28 \pm 3.86$ & $<0.05$ \\
Brain/liver ratio & $0.39 \pm 0.03$ & $0.52 \pm 0.08$ & $\mathrm{~ns}$ \\
CRL (cm) & $27.17 \pm 0.53$ & $25.75 \pm 0.67$ & $\mathrm{~ns}$ \\
Ponderal index $\left(\mathrm{g} / \mathrm{cm}^{3}\right)$ & $3.38 \pm 0.22$ & $2.99 \pm 0.11$ & $\mathrm{~ns}$ \\
\hline Valos are means $\pm \mathrm{SEM}^{3} \mathrm{c}$ & & &
\end{tabular}

Values are means \pm SEM. 
Maternal arterial plasma concentrations for insulin and IGF-I concentrations remained unaltered across early and mid gestation and there were no significant treatment effects (Fig. 1). Although umbilical venous concentrations of insulin in the 90 dGA HT group were reduced to $43 \%$ of control (Fig. 1), due to large variance in the data, statistical significance was not obtained $(p=0.15)$.

Figure 2 displays the relative mRNA concentrations of IGF-I, IGF-II, IGFBP-3 and IGFBP-4, in caruncle and cotyledon tissue. Caruncular IGF-I mRNA expression did not display an effect of gestational age; however, due to increased IGF-I mRNA expression in HT placentae at $90 \mathrm{dGA}$ there was a significant day by treatment interaction for caruncular IGF-I mRNA expression (Fig. 2A). No effect of gestational age or treatment was observed in cotyledon tissue. IGF-II expression in TN cotyledonary tissue increased significantly with gestational age (Fig. 2B). As a result of increased IGF-II mRNA in HT placentae at $55 \mathrm{dGA}$ (Fig. 2B), there was a significant day by treatment interaction $(p<0.01)$ for cotyledonary IGF-II mRNA concentration. In caruncular tissue, no effect of gestational age or treatment was observed.

IGFBP-1 was not detected in caruncle or cotyledon using $50 \mu \mathrm{g}$ of tcRNA. IGFBP-2 was detected in both caruncle and cotyledon tissue, however, due to inconsistent banding patterns, results were not suitable for analysis. Caruncular IGFBP-3 concentrations were consistent across gestation and were unaffected by treatment. However, cotyledonary IGFBP-3 declined with advancing gestation (Fig. 2C), though there were no treatment effects. IGFBP-4 mRNA concentration did not display gestational age effects in caruncular or cotyledon tissue. IGFBP-4 mRNA concentration was significantly elevated in HT caruncle tissue at $55 \mathrm{dGA}$, compared with control (Fig. $2 \mathrm{D}$ ).

TN fetal hepatic IGF-I mRNA concentrations increased with gestational age (Fig. 3A). There were no treatment effects on IGF-I mRNA concentration at either 55 or 90 dGA. IGF-II
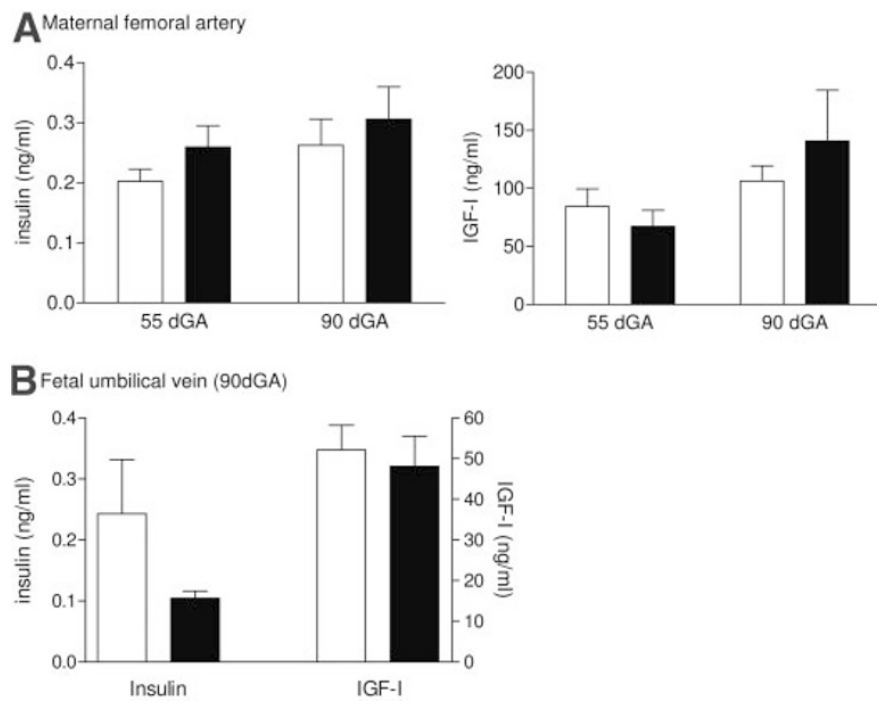

Figure 1. Maternal arterial $(A)$ and fetal venous umbilical $(B)$ concentrations

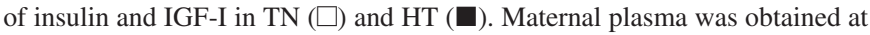
55 and $90 \mathrm{dGA}$, while fetal umbilical blood was sampled only in the $90 \mathrm{dGA}$ groups.
A IGF-I
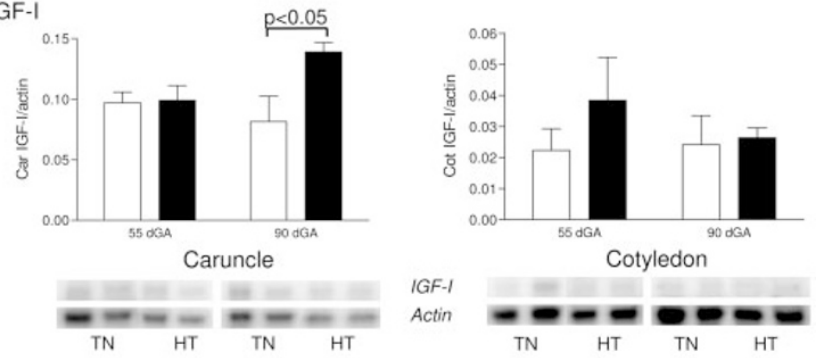

B IGF-II
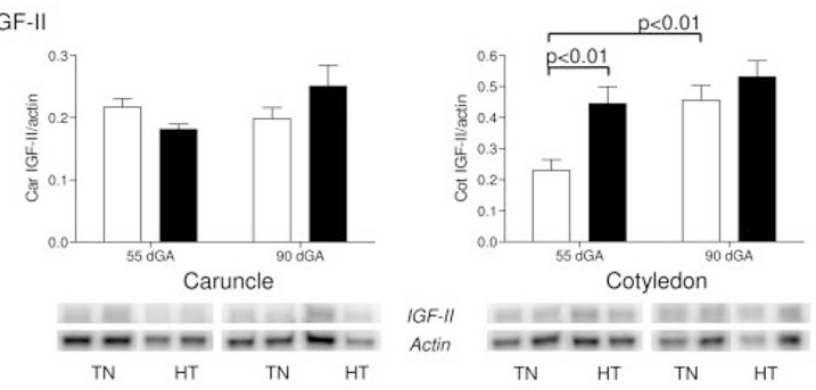

$\mathbf{C}_{\text {IGFBP-3 }}$
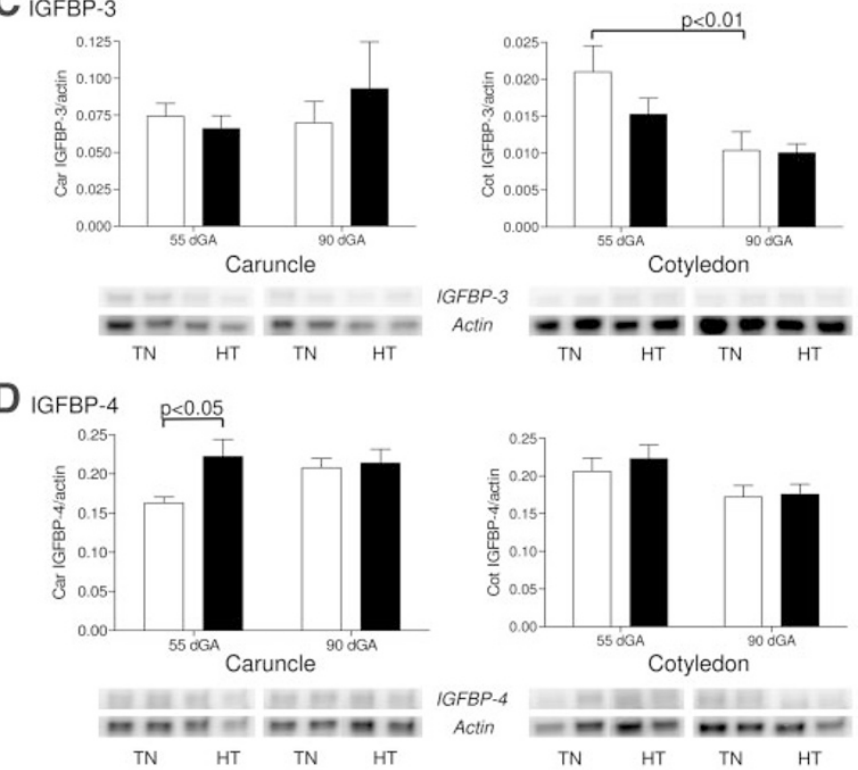

Figure 2. Concentration at 55 and $90 \mathrm{dGA}$ of ovine IGF-I $(A)$, IGF-II $(B)$, IGFBP-3 $(C)$ and IGFBP-4 $(D)$ mRNA (IGF(BP)/actin densitometry units) in TN $(\square)$ and HT (ם) maternal caruncle and fetal cotyledon tissue.

mRNA concentrations did not differ across early pregnancy, were not affected by treatment and were considerably greater than IGF-I mRNA concentrations (Fig. 3B). The concentration of IGFBP-2 (Fig. 3D), IGFBP-3 (Fig. $3 E$ ) and IGFBP-4 (Fig. $3 F$ ) mRNA increased significantly with gestational age, while IGFBP-1 remained unaltered (Fig. 3C). The IGFBPs studied were unaffected by treatment, though IGFBP-1 exhibited a trend toward increased levels at 90 dGA (Fig. 3C).

\section{DISCUSSION}

This study demonstrates that in a situation of early-onset placental and fetal growth restriction, circulating fetal and maternal plasma insulin and IGF-I levels remain unaltered, though fetal insulin concentrations tend to be reduced by mid gestation. Alterations do occur in placental tissue mRNA 

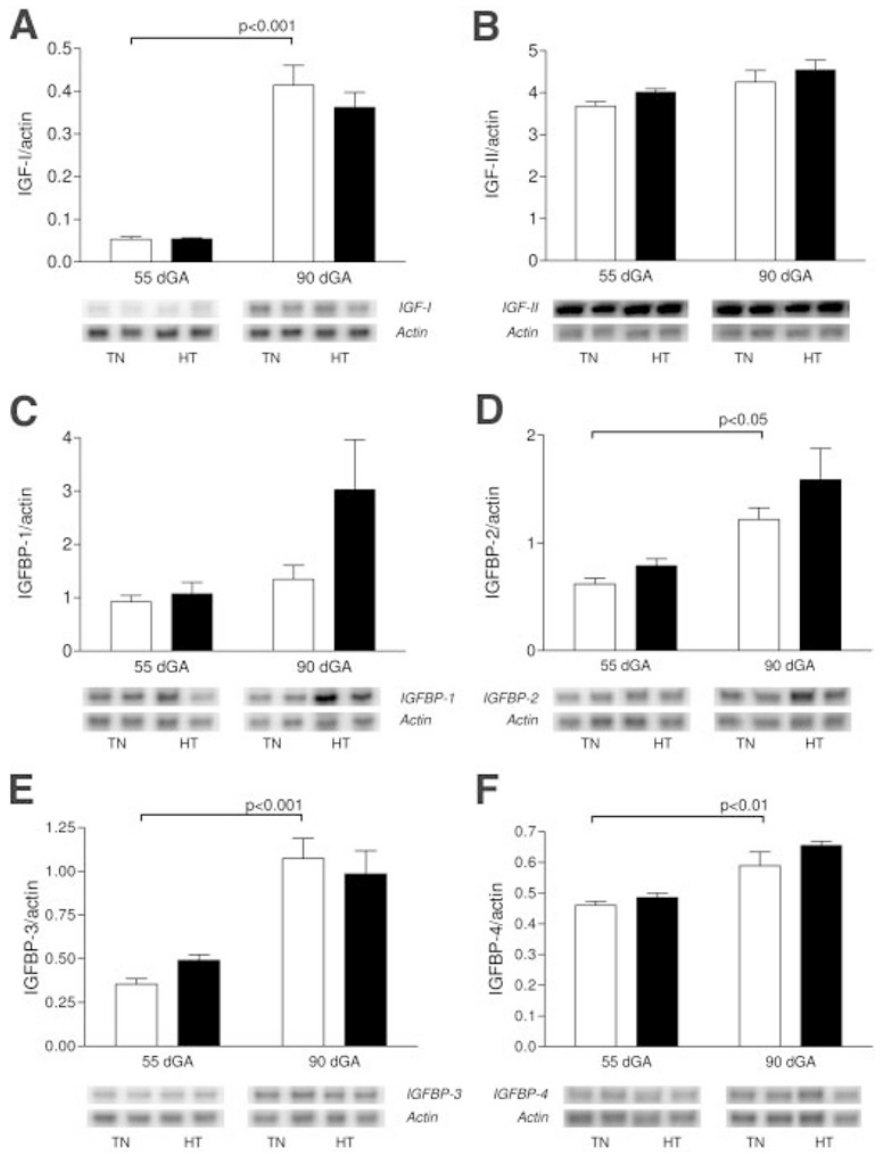

$\mathbf{F}$

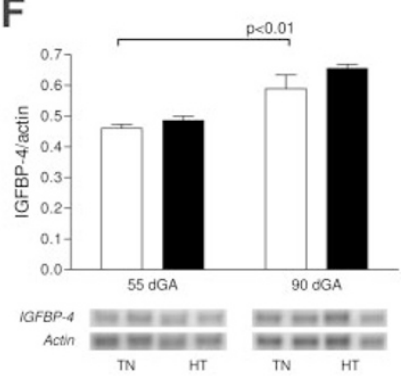

Figure 3. Fetal hepatic concentrations of IGF-I $(A)$, IGF-II $(B)$, IGFBP-1 $(C)$, IGFBP-2 $(D)$, IGFBP-3 $(E)$ and IGFBP-4 $(F)$ mRNA (IGF(BP)/actin densi-

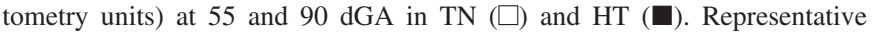
RNAse protection assay images are displayed in lower panels.

concentration for certain members of the IGF axis in early and mid gestation, though no evidence is found of changes in fetal hepatic expression of IGFs and IGFBPs. These changes occur concurrently with an increased fetal/placental ratio and brain/ liver ratio at $55 \mathrm{dGA}$ in $\mathrm{HT}$ pregnancies, and significant reductions in fetal and liver weights by 90 dGA.

Placental IGFs. During early and mid gestation, the placental expression of IGF-I mRNA is greater than in late pregnancy $(24,25)$, suggesting that IGF-I plays an important role in early placental development as a placental growth factor (25). Placental IGF-I expression is mainly localized to the maternal stroma (12), and although statistical comparison between the two tissue types is not possible, our data support previous localization observations. Aberrant placental IGF-I production has been implicated in IUGR $(6,26)$, where reduced fetal growth may have resulted from an inability of the placenta to increase placental nutrient transfer capacity (27). In the studies presented here, we observed a significant increase in caruncle IGF-I mRNA concentration of the HT placenta during mid gestation, while cotyledonary IGF-I mRNA was unaltered. Studies reporting the placental expression of IGF-I have focused on near term collection points and have reported conflicting data, with reports of no differences in placental IGF-I mRNA concentrations using PCR (28), while other reports document significant increases in placental
IGF-I mRNA through ISH and RNA dot blot techniques (24). Up-regulation of IGF-I mRNA in the HT caruncle at $90 \mathrm{dGA}$ may be an attempt to increase trophoblast differentiation, placental angiogenesis and nutrient transport, at a stage of pregnancy when fetal demands on the transport capacity of the placenta are normally increasing.

Placental vascular development is a particularly important aspect of placental development, setting the stage for later nutrient and gaseous exchange. The IGFs and IGFBPs play a role in implantation, early pregnancy and throughout gestation promoting vascular development $(11,29)$. The increased cotyledon IGF-II mRNA at $55 \mathrm{dGA}$ in the current study could play a role in altered placental angiogenesis. IGF-II mRNA is observed from $50 \mathrm{dGA}$ onwards in the sheep placenta, predominantly in the fetal mesenchyme tissues with lower concentrations in the caruncular stroma $(11,30)$. Coinciding with the increased IGF-II mRNA concentration, we have previously reported increased VEGF, Ang-1, Ang-2 and Tie-2 mRNA concentration in 55 dGA HT cotyledon $(19,31)$. IGF-II has a direct stimulatory effect on migration and proliferation of endothelial cells through binding to the IGF-II/Mannose6-phosphate receptor (32). Specifically, IGF-II appears to stimulate VEGF mRNA expression in monkey granulosa and keratinocyte cells $(33,34)$, through the MAP kinase pathway, by increasing HIF- $1 \alpha$, a potent inducer of VEGF mRNA transcription (33). Therefore, both growth factors, IGF-II and VEGF, may act together to stimulate tissue-specific cotyledonary angiogenesis during exposure to hyperthermic conditions, an effect that is most likely acute in nature, as by 90 dGA, both cotyledon VEGF (19) and IGF-II mRNA concentrations are no longer elevated. It is important to remember that while growth factor concentrations may be similar at the later stages of pregnancy, alterations in vascular development occurring earlier in pregnancy have potentially set the stage for later placental functional impairment through possible reductions in the total nutrient exchange surface area.

Placental IGFBPs. IGF binding protein 1 is the most prevalent IGFBP in the human uterus during implantation and facilitates trophoblast penetration at the maternal interface (29). However, in the less invasive sheep placenta, where a syncytialtrophoblast forms, expression of IGFBP-1 mRNA is localized to the luminal epithelium at $13 \mathrm{dGA}$, before attachment of the embryo, and becomes undetectable by $21 \mathrm{dGA}$ (35). The failure to detect IGFBP-1 in cotyledon or caruncle in the present study is in agreement with this previous report and may reflect differences in trophoblast invasion mechanisms between different species (35). Additionally, there may be a redundancy between the various types of IGFBP, and different species may use different IGFBPs for similar functions (12). The concentration of IGFBP-3 mRNA decreased in cotyledons with increasing gestational age. These findings are in concordance with an earlier ontogenetic study in control sheep placenta, where IGFBP-3 is expressed in high concentrations in the luminal epithelium in early gestation (13-15 dGA), suggesting a role in implantation, after which concentrations remain low (11). In the caruncle, IGFBP-3 levels are reportedly higher and localized to maternal vessel walls, where it is 
postulated to play a role in the transfer of IGFs from circulation to target tissues (11).

Concomitantly with the up-regulation of IGF-II in cotyledon, IGFBP-4 mRNA expression is increased in the $55 \mathrm{dGA}$ HT caruncle. IGFBP-4 has been localized to the caruncular capsule and stroma in ovine pregnancy and in stroma underlying the luminal epithelium. Similarly, IGFBP-4 has been localized adjacent to implantation sites in murine pregnancy (11), and has been suggested to play a physiologic role in the implantation process. IGFBP-4 has been demonstrated to inhibit the actions of the IGFs in bone and neuronal cells $(1,36)$, and the increased co-expression of IGF-II in cotyledon and IGFBP-4 in caruncle at early gestation suggests that IGFBP-4, rather than IGFBP-1 may play an important role in regulating IGF-II effects at the maternal-fetal interface of the sheep placenta, possibly limiting trophoblast epithelium interaction and exchange surface area development.

Fetal hepatic IGF and IGFBP concentration. Hepatic expression of IGF-I and IGFBP-2, -3 and -4 are developmentally regulated and in control TN tissues show a significant increase with gestational age, similar to changes observed in other fetal organ studies $(3,30,37)$, while concentrations of IGFBP-1 tend to be increased. In agreement with other models of growth restriction, hepatic IGF-II expression is more abundant than that of IGF-I, remains unchanged throughout the early and mid stages of pregnancy and lacks a significant relationship with placental restriction $(38,39)$. Furthermore, this study demonstrates no significant effect of treatment on fetal hepatic IGF and IGFBP concentration during early or mid-gestation.

In this report no change in hepatic IGFBP-1 mRNA concentration was observed during early fetal development, though at $90 \mathrm{dGA}$, before maximal fetal growth, IGFBP-1 mRNA exhibited a trend to be up-regulated, suggestive of increased expression as seen later in pregnancy in other models of placental insufficiency (40). IGFBP-1 responds to chronic changes in nutritional status or oxygenation (7), therefore, the failure to demonstrate an increase in fetal hepatic IGFBP-1 suggests that the HT fetuses are likely not chronically hypoxic or hypoglycemic at this early stage of gestation. Studies performed in late gestation human IUGR demonstrate increases in plasma IGFBP-1 and hepatic IGFBP-1 mRNA concentrations, and decreases in IGF-I and IGFBP-3 in fetal plasma and liver $(5,6,41)$. Similar alterations are not apparent in early and mid-gestation IUGR sheep, suggesting that the changes in the IGF axis during late gestation may be secondary to the near term, hypoxic, hypoglycemic and hypoinsulinemic stage of fetal growth restriction.

\section{CONCLUSIONS}

This study describes fetal and placental changes in expression of the IGFs and four of its binding proteins in early and mid-gestation in a model of IUGR, caused by a placental insult in early gestation. The observed greater fetal/placenta ratio at 55 dGA that was attenuated by 90 dGA suggests a number of developmental processes occur in response to the insult. Firstly, the increased ratio is supportive of an impaired
IGF-II/IGFBP-4 driven placental development process early in gestation that later in pregnancy manifests itself through reduced nutrient delivery to the developing fetus. Secondly, the maintenance of fetal weight at 55 dGA suggests that an improved functional placenta actually results, perhaps as an acute compensatory response to stress. Although by $90 \mathrm{dGA}$, while fetal IGFs are unaltered, fetal weight and liver weight have become significantly decreased, suggesting that compensatory effects that occurred early in gestation have now failed. These reductions in fetal and liver weight support the concept that by $90 \mathrm{dGA}$, before maximal fetal growth, placental nutrient supply is already impaired. This reduced nutrient supply could be manifested by reductions in trophoblast epithelium development and subsequent nutrient exchange surface area such that fetal growth is now reduced. From other studies in this model we know that $45 \mathrm{~d}$ later, by $135 \mathrm{dGA}$ (15), fetuses are hypoglycemic and display reduced IGF levels. This implies that at $90 \mathrm{dGA}$, the impact of the in utero nutritional environment upon fetal IGF production and subsequent growth is just emerging. Combined, these data suggest that subtle changes in placental IGF expression in early gestation may predispose the developing placenta to functional insufficiency, resulting in inadequate substrate supply to the developing fetus.

\section{REFERENCES}

1. Mohan S, Baylink DJ 2002 IGF-binding proteins are multifunctional and act via IGF-dependent and -independent mechanisms. J Endocrinol 175:19-31

2. Liu JP, Baker J, Perkins AS, Robertson EJ, Efstratiadis A 1993 Mice carrying null mutations of the genes encoding insulin-like growth factor I (Igf-1) and type 1 IGF receptor (Igf1r). Cell 75:59-72

3. Carr JM, Owens JA, Grant PA, Walton PE, Owens PC, Wallace JC 1995 Circulating insulin-like growth factors (IGFs), IGF-binding proteins (IGFBPs) and tissue mRNA levels of IGFBP-2 and IGFBP-4 in the ovine fetus. J Endocrinol 145:545-557

4. Kind KL, Owens JA, Robinson JS, Quinn KJ, Grant PA, Walton PE, Gilmour RS, Owens PC 1995 Effect of restriction of placental growth on expression of IGFs in fetal sheep: relationship to fetal growth, circulating IGFs and binding proteins. J Endocrinol 146:23-34

5. Ong K, Kratzsch J, Kiess W, Costello M, Scott C, Dunger D 2000 Size at Birth and Cord Blood Levels of Insulin, Insulin-Like Growth Factor I (IGF-I), IGF-II, IGFBinding Protein-1 (IGFBP-1), IGFBP-3, and the Soluble IGF-II/Mannose-6Phosphate Receptor in Term Human Infants. J Clin Endocrinol Metab 85:4266-4269

6. Larsen T, Main K, Andersson AM, Juul A, Greisen G, Skakkebaek NE 1996 Growth hormone, insulin-like growth factor I and its binding proteins 1 and 3 in last trimester intrauterine growth retardation with increased pulsatility index in the umbilical artery. Clin Endocrinol 45:315-319

7. McLellan KC, Hooper SB, Bocking AD, Delhanty PJ, Phillips ID, Hill DJ, Han VK 1992 Prolonged hypoxia induced by the reduction of maternal uterine blood flow alters insulin-like growth factor-binding protein-1 (IGFBP-1) and IGFBP-2 gene expression in the ovine fetus. Endocrinology 131:1619-1628

8. Giudice LC, de Zegher F, Gargosky SE, Dsupin BA, de las Fuentes L, Crystal RA, Hintz RL, Rosenfeld RG 1995 Insulin-like growth factors and their binding proteins in the term and preterm human fetus and neonate with normal and extremes of intrauterine growth. J Clin Endocrinol Metab 80:1548-1555

9. Tapanainen PJ, Bang P, Wilson K, Unterman TG, Vreman HJ, Rosenfeld RG 1994 Maternal hypoxia as a model for intrauterine growth retardation: effects on insulinlike growth factors and their binding proteins. Pediatr Res 36:152-158

10. Ehrhardt RA, Bell AW 1995 Growth and metabolism of the ovine placenta during mid-gestation. Placenta 16:727-741

11. Reynolds TS, Stevenson KR, Wathes DC 1997 Pregnancy-specific alterations in the expression of the insulin-like growth factor system during early placental development in the ewe. Endocrinology 138:886-897

12. Han VK, Carter AM 2000 Spatial and temporal patterns of expression of messenger RNA for insulin-like growth factors and their binding proteins in the placenta of man and laboratory animals. Placenta 21:289-305

13. Gallaher BW, Breier BH, Keven CL, Harding JE, Gluckman PD 1998 Fetal programming of insulin-like growth factor (IGF)-I and IGF-binding protein-3: evidence for an altered response to undernutrition in late gestation following exposure to periconceptual undernutrition in the sheep. J Endocrinol 159.501-508

14. McMullen S, Osgerby JC, Milne JS, Wallace JM, Wathes DC 2005 The effects of acute nutrient restriction in the mid-gestational ewe on maternal and fetal nutrient status, the expression of placental growth factors and fetal growth. Placenta $26: 25-33$ 
15. Thureen PJ, Trembler KA, Meschia G, Makowski EL, Wilkening RB 1992 Placental glucose transport in heat-induced fetal growth retardation. Am J Physiol 263:R578R585

16. Regnault TR, de Vrijer B, Galan HL, Davidsen ML, Trembler KA, Battaglia FC, Wilkening RB, Anthony RV 2003 The relationship between transplacental $\mathrm{O}_{2}$ diffusion and placental expression of PlGF, VEGF and their receptors in a placental insufficency model of fetal growth restriction. J Physiol 550:641-656

17. Regnault TR, Galan HL, Parker TA, Anthony RV 2002 Placental development in normal and compromised pregnancies - A review. Placenta 23:S119-S129

18. Regnault TR, Orbus RJ, Battaglia FC, Wilkening RB, Anthony RV 1999 Altered arterial concentrations of placental hormones during maximal placental growth in a model of placental insufficiency. J Endocrinol 162:433-442

19. Regnault TR, Orbus RJ, de Vrijer B, Davidsen ML, Galan HL, Wilkening RB, Anthony RV 2002 Placental expression of VEGF, PlGF and their receptors in a model of placental insufficiency-intrauterine growth restriction (PI-IUGR). Placenta 23:132-144

20. Vatnick I, Bell AW 1992 Ontogeny of fetal hepatic and placental growth and metabolism in sheep. Am J Physiol 263:R619-R623

21. Stegmann JH 1974 Placental development in the sheep and its relation to fetal development. Bijdragen tot de Dierkunde 44:4-72

22. Limesand SW, Hay WW Jr 2003 Adaptation of ovine fetal pancreatic insulin secretion to chronic hypoglycaemia and euglycaemic correction. J Physiol 547:95105 .

23. Nagatani S, Zeng Y, Keisler DH, Foster DL, Jaffe CA 2000 Leptin regulates pulsatile luteinizing hormone and growth hormone secretion in the sheep. Endocrinology 141:3965-3975

24. Sheikh S, Satoskar P, Bhartiya D 2001 Expression of insulin-like growth factor-I and placental growth hormone mRNA in placentae: a comparison between normal and intrauterine growth retardation pregnancies. Mol Hum Reprod 7:287-292

25. Wang CY, Daimon M, Shen SJ, Engelmann GL, Ilan J 1988 Insulin-like growth factor-I messenger ribonucleic acid in the developing human placenta and in term placenta of diabetics. Mol Endocrinol 2:217-229

26. Nieto-Diaz A, Villar J, Matorras-Weinig R, Valenzuela-Ruiz P 1996 Intrauterine growth retardation at term: association between anthropometric and endocrine parameters. Acta Obstet Gynecol Scand 75:127-131

27. Sorem KA, Siler-Khodr TM 1998 Placental IGF-I in severe intrauterine growth retardation. J Matern Fetal Med 7:1-7

28. Abu-Amero SN, Ali Z, Bennett P, Vaughan JI, Moore GE 1998 Expression of the insulin-like growth factors and their receptors in term placentas: a comparison between normal and IUGR births. Mol Reprod Dev 49:229-235

29. Han VK, Bassett N, Walton J, Challis JR 1996 The expression of insulin-like growth factor (IGF) and IGF-binding protein (IGFBP) genes in the human placenta and membranes: evidence for IGF-IGFBP interactions at the feto-maternal interface. J Clin Endocrinol Metab 81:2680-2693

30. Delhanty PJ, Han VK 1993 The expression of insulin-like growth factor (IGF)binding protein-2 and IGF-II genes in the tissues of the developing ovine fetus. Endocrinology 132:41-52

31. Hagen AS, Orbus RJ, Wilkening RB, Regnault TR, Anthony RV 2005 Placental expression of angiopoietin-1, angiopoietin-2 and tie-2 during placental development in an ovine model of placental insufficiency-fetal growth restriction. Pediatr Res 58:1228-1232

32. Volpert O, Jackson D, Bouck N, Linzer DI 1996 The insulin-like growth factor II/mannose 6-phosphate receptor is required for proliferin-induced angiogenesis. Endocrinology 137:3871-3876

33. Kwon YW, Kwon KS, Moon HE, Park JA, Choi KS, Kim YS, Jang HS, Oh CK, Lee YM, Kwon YG, Lee YS, Kim KW 2004 Insulin-like growth factor-II regulates the expression of vascular endothelial growth factor by the human keratinocyte cell line HaCaT. J Invest Dermatol 123:152-158

34. Martinez-Chequer JC, Stouffer RL, Hazzard TM, Patton PE, Molskness TA 2003 Insulin-like growth factors-1 and -2, but not hypoxia, synergize with gonadotropin hormone to promote vascular endothelial growth factor-A secretion by monkey granulosa cells from preovulatory follicles. Biol Reprod 68:1112-1118

35. Wathes DC, Reynolds TS, Robinson RS, Stevenson KR 1998 Role of the insulin-like growth factor system in uterine function and placental development in ruminants. J Dairy Sci 81:1778-1789

36. Cheung PT, Smith EP, Shimasaki S, Ling N, Chernausek SD 1991 Characterization of an insulin-like growth factor binding protein (IGFBP-4) produced by the B104 rat neuronal cell line: chemical and biological properties and differential synthesis by sublines. Endocrinology 129:1006-1015

37. Langford K, Nicolaides K, Miell JP 1998 Maternal and fetal insulin-like growth factors and their binding proteins in the second and third trimesters of human pregnancy. Hum Reprod 13:1389-1393

38. Owens JA, Kind KL, Carbone F, Robinson JS, Owens PC 1994 Circulating insulin-like growth factors-I and -II and substrates in fetal sheep following restriction of placental growth. J Endocrinol 140:5-13

39. Jensen EC, Harding JE, Bauer MK, Gluckman PD 1999 Metabolic effects of IGF-I in the growth retarded fetal sheep. J Endocrinol 161:485-494

40. Unterman T, Lascon R, Gotway MB, Oehler D, Gounis A, Simmons RA, Ogata ES 1990 Circulating levels of insulin-like growth factor binding protein- 1 (IGFBP-1) and hepatic mRNA are increased in the small for gestational age (SGA) fetal rat. Endocrinology 127:2035-2037

41. Fant M, Salafia C, Baxter RC, Schwander J, Vogel C, Pezzullo J, Moya F 1993 Circulating levels of IGFs and IGF binding proteins in human cord serum: relationships to intrauterine growth. Regul Pept 48:29-39 